\title{
Effective Application of Micro Course in College French Class under the Background of Mobile Media
}

\author{
Li Yang \\ College of Liberal Arts, Xi'an International University, Xi'an, Shaanxi, 710077
}

Keywords: Background of Mobile Media; Micro Lecture; College French Class; Application

\begin{abstract}
Under the background of mobile media, the speed of globalization is faster and faster, the economic and cultural exchanges between different countries are gradually deepening, more and more foreigners begin to learn Chinese, and at the same time, a number of foreign language have been learned by Chinese people. French, as the second world universal language, is playing a more and more important role in today's social practice. The purpose of the college French course in China is to help contemporary college students master the skills of oral French expression and improve their comprehensive ability of French application. This paper mainly discusses the concept, characteristics and effective application of micro course as a new type of teaching method in college French class.
\end{abstract}

Under the background of mobile media, the university education work faces the new opportunities and the challenges. As the acceleration of the globalization, the exchange between different languages and cultures is becoming more and more frequent. French, as the second universal language in the world after English, is playing an increasingly important role in the world. As a result, Chinese college education has followed the development of the times, and has offered French course and other languages. In the new era, it is necessary to establish a new educational system and educational model. In the classroom teaching of college French, the use of modern mobile media tools has become the trend of the times. Micro course is a new teaching method derived from computer technology and mobile network technology. The effective application of micro course in college French class can make up for the defects of traditional teaching model and improve the effectiveness of classroom teaching.

\section{Present situation of college French teaching under the background of mobile media.}

The new social background brings new opportunities and challenges to all fields, and the field of university education is no exception. Nowadays, college French classroom teaching is inseparable from the extensive application of modern information technology and mobile multimedia equipment. Compared with the traditional classroom teaching model, the new educational concept and educational model have brought more convenient conditions and more abundant teaching ways to the teachers' classroom teaching work ${ }^{[1]}$. Teachers can dig into and use a variety of network teaching resources, widen the coverage of teaching content, construct a more open language learning environment, and improve the efficiency of classroom teaching by using various information technology means, so as to fully meet the needs of contemporary college students in the study of French. At the same time, based on the development and application of mobile media technology and information equipment, a variety of new classroom teaching methods have been unprecedented development, micro course is one of them. The emergence of micro course breaks the limitation of traditional classroom such as time, location and space, makes the content of college French classroom teaching more targeted and effective, and greatly improves the students' learning effect in classroom. However, how to master the flexibility of the application of micro course and improve the quality of micro course is still a problem that the college French teachers must ponder. 


\section{Feasibility of micro course in college French class}

The purpose of college French course is to help the student master basic knowledge of French and skills of oral expression, and to cultivate students' ability of listening, speaking, reading and writing. Only relying on a single textbook and the explanation in classroom can not achieve the ideal teaching effect ${ }^{[2]}$. The application of micro course in French class can transform dull language into vivid short image video, which makes abstract and complicated words more concrete and visualized, and stimulates students' study initiative. Compared with the tediously long classroom teaching process, students obviously prefer the short micro course that has different genres and interesting contents, and that is not available in any other teaching methods. It is accord with the fast learning rhythm of the contemporary college students.

The introduction of micro course in college French teaching can complement and extend the classroom teaching. In the process of classroom teaching, the proper insertion of video of micro course can not only improve the vividness of classroom teaching, but also help to stimulate the students' brain, reduce the students' sense of learning weariness, and improve the efficiency of the whole class. For example, in French pronunciation, situational dialogue and other practical teaching segments, by collecting network case resources and making short videos for students to listen and repeat, so as to supplement the teaching contents in textbooks and improve the learning effect.

Micro course has the advantages of convenience and brevity. The application of micro course in the teaching of French can make the students' study more substantial and break through the limitation of traditional classroom teaching in place and space, so as to realize the dynamic learning anytime, anywhere ${ }^{[3]}$. The popularity of electronic mobile devices provides a more convenient condition for the application of micro course. The students only need to use a computer or a mobile phone to learn French. They can learn and study the content of the micro course video repeatedly. At the same time, the students can make full use of their free time and arrange their learning time independently. In addition, publishing micro course teaching resources on the network teaching platform or the WeChat public platform of the school that specializes in curricula can make students' daily learning more convenient and reduce teachers’ working pressure.

\section{Discussion and Analysis on the procedure of preparing Micro course}

Unlike the requirements of traditional classroom teaching, teachers do not need to prepare a large number of notes on teaching content, and the application of micro course does not require teachers to organize too many languages on their own. Instead, it sets a higher standard for teachers' computer skills and video production capabilities. In order to improve the teaching effect of micro course, the teachers must first improve the quality of their micro course. The procedure of producing micro course usually includes the following processes:

Based on mobile network technology, micro course have the characteristics of fragmentation, spatial diversification and so on. The topics of micro courses are mostly short and refined ${ }^{[4]}$. The topics of French micro course must be simple and easy to understand, close to the subject of teaching content, meanwhile, it can be combined with some important grammatical points, knowledge of French pronunciation, etc.

The emphasis of the so called micro course is on the word "micro". As we all know, the duration of a courseware of micro course is generally controlled in about ten minutes, which means that the teachers must scientifically analyze, summarize and integrate a lot of classroom knowledge points, and then, concentrate these points into the short courseware and complete the teaching task. Therefore, when the teachers make micro course courseware, they can apply typical cases appropriately, combine the students' life reality, create the corresponding teaching circumstance for them, let the students deepen the understanding of the knowledge by the case analysis, so that the students can applied the knowledge to the real life, that is "learn quick, apply well".

Because micro course have the characteristics of miniaturization, the teacher should first integrate the teaching content with the plan of making a micro course, which is called multimedia 
script. After that, the people involved in video production, including post editing staff, should make and edit the course according to the content of multimedia script, so as to realize the trinity, and to ensure the quality of the micro course and the teaching effect. To this end, the teacher must improve their own application and operation ability of computer.

\section{Countermeasures for effective application of micro course in college French class under the background of mobile media}

Under the background of mobile media, the introduction and application of micro course in college French teaching has become a general trend. Because the duration of micro course and the amount of teaching content are very limited, so, how to display the teaching content in a short time and improve the teaching effect of the students is the key point of micro course teaching. College French teachers must make clear the teaching characteristics of micro-courses ${ }^{[5]}$. The college French teachers should have a good understand about the characteristic of micro course, and in the teaching practice, take the refined small micro course as the primary, then summarize and induce the relevant targeted and planned points of knowledge, so as to ensure the pertinence of micro course teaching. For example, when teaching French words such as "Bonsoir" (good evening) and "Salut" (goodbye), you can first collect videos of meetings in French on the web, then choose these materials for editing such as "-Comment allez-vous?" (How are you?) “-Tr è s bienfen! Et vous?” (Good, thanks, and you?). By playing this kind of brief video about daily conversation, it gives the students a comprehensive understanding of the etiquette of meeting in France. This way of watching the video not only helps the students master some basic knowledge of French, but also help the students to understand the etiquette of daily life in France, such as kiss and so on, so as to improve the students' language communicative application ability, and to deepen the students' impression of the relevant vocabulary. By organizing, integrating the points of complicated and numerous points of knowledge, the teachers can introduce the tiny knowledge modules and highlight the key teaching points, so as to improve the efficiency of class teaching.

Teachers should first understand that micro course can not completely replace traditional classroom teaching; it is only a supplement and extension of traditional classroom teaching ${ }^{[6]}$. In the process of micro course design and arrangement, teachers can not completely abandon the function of traditional classroom teaching; they should combine the structure of classroom teaching, and take the textbook as the core material, and then design the course reasonably. It is mainly to sum up all kinds of scattered knowledge points, to integrate and optimize the same type of knowledge points, to highlight the important and difficult teaching contents of teaching materials, to deconstruct and explain this part of the content, and to optimize the classroom teaching model, so as to realize the teaching function of micro course. For this reason, teachers must strengthen their ability to apply information technology, improve their information ability, set up new educational concepts, strengthen the research on new network mobile devices and multimedia devices, and master video production techniques and recording methods. At the same time, the teachers should master the software and application of video post processing, be able to edit the video skillfully, so as to ensure the display effect of micro course video. Under the background of mobile media, improving information ability is the actual work that educators must know well.

College students already have mature ideological cognition and autonomous behavior ability. In the classroom teaching of college French, teachers can introduce the flipping classroom teaching model so as to promote the improvement of the teaching effect of micro course, to fully stimulate the students' consciousness of self learning, and to improve the students' ability of independent research and innovation. At present, many college students are lazy in learning, unable to concentrate on listening and learning in classroom teaching, and even tired of curriculum learning. The application of flipping classroom aims for improving the present situation and ensuring the maximization of teaching effect. The improvement of learning effect depends on the students' self learning behavior. So, the teachers should start from the students' actual situations, establish the teaching mechanism of preparation, study, review of the course, and perfect the feedback system of teaching evaluation, so as to improve the teaching quality of French. For example, the teachers can 
guide the students to sum up the teaching knowledge independently according to their own actual situation after explaining the micro course knowledge point in a certain stage, and then, guide the students build their own knowledge system to find out the key points of the later review work. The teachers also can let the students discuss in groups, share learning resources and grammar knowledge, set up French interest groups, carry out classroom French research activities, so as to improve the students' practical application ability and oral expression ability by the help of micro course.

\section{Conclusion}

In the new period, college French teaching staff must have new teaching concepts, learn and master more new network media technology, improve their information ability, realize teaching innovation, and make full use of the advantages brought by mobile media technology. At the some time, the staff should strengthen the improvement and application of micro course, promote the deep integration of modern teaching methods and traditional teaching advantages, rationally apply flipping class, stimulate students' consciousness of self learning, and stimulate students' enthusiasm for learning French. The micro course can play an important role in the classroom teaching of college French, and improve the students' language application ability and comprehensive learning accomplishment.

\section{References}

[1] Li Jia. Research on Teaching Reform and Development of College French Course under the Background of “Internet+" [J]. New Campus, 2017(07):167-168.

[2] Wu Panpan. A Preliminary Analysis of the Application of Micro Course in College French Class

[J]. Course Education Research, 2017(28):113.

[3] Chen Youzhu. Brief Analysis and Discuss on Network Resources Are Applied to Teach French as a Second Foreign Language [J]. Journal of Sichuan Provincial Correspondence Institute for Administrators, 2016(04):113-115.

[4] Shi Jingdan. On the Complementarity Between Micro Course and Teaching French as a Second Foreign language under the Background of “Internet+”[J]. Home Drama, 2018(12):178.

[5] Wang Jing Research on the Class Efficiency of French Major in Vocational College [D]. Hebei Normal University of Science \& Technology, 2017.

[6] Fang Linlin. A Preliminary Analysis of Applying Network Resources to Teach French as a Foreign Language [J]. Journal of Beijing University of Posts and Telecommunications (Social Sciences Edition), 2015, 17(01):101-106. 